\title{
Penerapan Metode Box Muller of Gaussian Distribution Untuk Menentukan Tingkat Kesulitan Pada Game Pembelajaran Mitigasi Bencana Gunung Api
}

\author{
Afif Nuril Ihsan, Fresy Nugroho, Yunifa Miftachul Arif
}

\begin{abstract}
Abstrak - the difficulty level scenario in a game is an important component in making a game. In order for the game difficulty level scenario to be more challenging and not monotonous, the difficulty level scenario must be determined automatically or dynamically. In this study, the determination of the difficulty level scenario will be built with the Box Muller Of Gaussain Distribution method so that the difficulty level scenario can run automatically or dynamically, so that the scenario can be chosen randomly and cannot be predicted by the player. In this study, the difficulty level scenario is used in the Volcano Disaster Mitigation Learning game to manage the difficulty of science problems that will appear at each level. In the testing phase, two tests will be conducted between the game of Volcano Disaster Mitigation Learning with the Box Muller Of Gaussian Distribution method and without the method. From this testing phase it was found that the game using more varied methods in determining the level of difficulty scenarios. In this testing phase, the ideal mean for the 4th grade students is $\mu=5.5$. Then the validation stage will be used behavior validation by finding 5 4th grade elementary school students to play the game. Of the 5 students who tried the game Volcano Disaster Mitigation Learning, the results showed that, the first student had an average success of $71.11111 \%$, the second student got $81.48148148 \%$, the third student $79.16666667 \%$, the fourth student $73.61111111 \%$, and the fifth student $87.5 \%$. From this study it was concluded that the Box Muller of Gaussian Distribution managed to manage the difficulty level scenario dynamically or automatically.
\end{abstract}

Index Terms- Behavior Validation, Box Muller, Dynamic Difficulty Level, Game, Gaussian Distribution.

Abstrak-tingkat kesulitan pada game merupakan komponen penting dalam pembuatan game. Supaya

Manuscript received March 22, 2019. This work was supported in part by Informatics Engineering Department of Maulana Malik Ibrahim Islamic State University.

Afif Nuril Ihsan is with the Informatic Engineering Departement of Maulana Malik Ibrahim Islamic State University, Malang, Indonesia (email: fresysss@gmail.com )

Fresy Nugroho, was with the Informatic Engineering Departement of Maulana Malik Ibrahim Islamic State

Yunifa Miftachul Arif is the Informatic Engineering Departement of Maulana Malik Ibrahim Islamic State University, Malang, Indonesia (email yunif4@gmail.com) skenario tingkat kesulitan game lebih menantang dan tidak monoton maka skenario tingkat kesulitan harus ditentukan secara otomatis atau dinamis. Dalam penelitian ini, penentuan skenario tingkat kesulitan akan dibangun dengan metode Box Muller Of Gaussain Distribution supaya skenario tingkat kesulitan dapat berjalan secara otomatis atau dinamis, sehingga skenario bisa dipilih secara acak dan tidak bisa diprediksi oleh pemain. Pada penelitian ini skenario tingkat kesulitan digunakan pada game Pembelajaran Mitigasi Bencana Gunung Api untuk mengatur kesulitan soal IPA yang akan muncul pada tiap level. Pada tahap pengujian akan dilakukan dua pengujian antara game Pembelajaran Mitigasi Bencana Gunung Api dengan metode Box Muller Of Gaussian Distribution dan tanpa metode. Dari tahap pengujian ini didapat bahwa game yang menggunakan metode lebih bervariasi dalam penentuan skenario tingkat kesulitan. Pada tahap pengujian ini didapat mean / rata-rata ideal untuk siswa kelas 4 SD yaitu $\boldsymbol{\mu}=5.5$. Kemudian tahap validasi akan digunakan validasi behavior dengan cara mencari 5 siswa kelas 4 SD untuk memainkan permainan. Dari 5 siswa yang mencoba game Pembelajaran Mitigasi Bencana Gunung Api didapat hasil bahwa, siswa pertama memiliki rata-rata keberhasilan $\mathbf{7 1 . 1 1 1 1 1 \%}$, siswa kedua mendapatkan $81.48148148 \%$, siswa ketiga $79.16666667 \%$, siswa keempat $73.6111111 \%$, dan siswa kelima $87.5 \%$. Dari penelitian ini didapat kesimpulan bahwa Box Muller of Gaussian Distribution berhasil mengatur skenario tingkat kesulitan secara dinamik atau otomatis.

Kata Kunci-Box Muller, Game, Gaussian Distribution, Tingkat Kesulitan Dinamis, Validasi Behavior.

\section{I.PENDAHULUAN}

Dada saat ini teknologi berkembang sangat pesat, khususnya teknologi pembuatan game. Game pada saat ini dapat dengan mudah di akses dan dimainkan oleh berbagai kalangan. Bermain game dapat meringankan dan mengalihkan perhatian dari rasa sakit yang diderita oleh seorang anak yang sedang dalam masa perawatan, misalnya seperti kemoterapi [1]. Dalam sebuah game terdapat beberapa komponen game seperti, skenario game merupakan gambaran alur cerita pada game. Dalam game juga terdapat NPC atau Non Player Character. Selanjutnya dalam game terdapat tema atau genre game, misal game edukasi, 
petualangan, aksi, RPG, dan lain-lain. Desain rintangan dalam skenario game merupakan salah satu faktor yang dapat mempengaruhi motivasi pemain dalam bermain [2]. Bermain game juga dapat membuat merasa bosan. Kebosanan pemain memainkan sebuah game didasarkan pada beberapa faktor, salah satunya adalah desain rintangan pada skenario game. Terdapat penentuan tingkat kesulitan pada game dengan cara otomatis atau dinamis, jadi pemain tidak perlu memilih tingkat kesulitan game pada awal bermain game, seperti easy, medium atau hard. Jika dibangun secara otomatis atau dinamis maka kesulitan game dapat berubah sesuai dengan kemampuan pemainnya.

Metode pertama yang dapat membuat skenario tingkat kesulitan secara dinamik atau otomatis yaitu Central Limit Theorem Approximation, metode ini dapat digunakan dalam penentuan tingkat kesulitan akan tetapi variabel yang diacak pada metode ini yaitu many uniform random variables. Metode ini memiliki kekurangan terlalu banyaknya variabel yang diacak, semakin banyak variabel yang diacak maka proses akan semkin lama. Metode kedua yaitu Box-Muller of Gaussian Distribution, metode ini dapat menentukan tingkat kesulitan game secara otomatis atau dinamis. Box-Muller of Gaussian Distribution ini melakukan operasi acak untuk menentukan tingkat kesulitan game dengan mengacak dua variabel saja [3].

Pada permasalahan yang diuraikan, ditawarkan sebuah solusi Bagaimana menentukan tingkat kesulitan game secara dinamis atau otomatis menggunakan metode Box Muller of Gaussian Distribution.

\section{II.PENELITIAN TERKAIT}

Penelitian sejenis yang pernah dilakukan yaitu pada penelitian yang membahas metode Box Muller of Gaussian Distribution untuk penentuan tingkat kesulitan pada game Reog Ponorogo yang dibuat oleh I Nyoman Sukajaya pada tahun 2015. Inti dari penelitian ini adalah membahas cara penentuan skenario tingkat kesulitan secara dinamik dan dinamis [4]. Penelitian sejenis yang lain yaitu untuk Selanjutnya penentuan tingkat kesulitan pada game penentuan lorong yang terbuka dengan menyelesaikan soal matematika Pada paper ini terdapat 3 tipe soal matematika yaitu sulit, sedang, dan mudah. Tiga tipe soal ini akan membuka lorong untuk bertemu dewa untuk meminta suatu petunjuk. Tiap tipe soal akan membuka lorong yang berbeda jika skor yang didapat sesuai dengan ketentuan [5]. Penelitian sejenis yang lain dimana peneliti penentukan tingkat kesulitan secara dinamis pada game Labirin dengan metode algoritma logika fuzzy Untuk pengujian pada jurnal ini menggunakan dua pengujian, pengujian validasi behavior dan pengujian performa. Dari jurnal ini dapat disimpulkan bahwa metode fuzzy berhasil untuk menyetarakan softskill yang dimiliki pemain dengan level yang dimainkan [6].

\section{III.ALUR PENGUMPULAN DATA}

\section{A. Blok Diagram Penelitian}

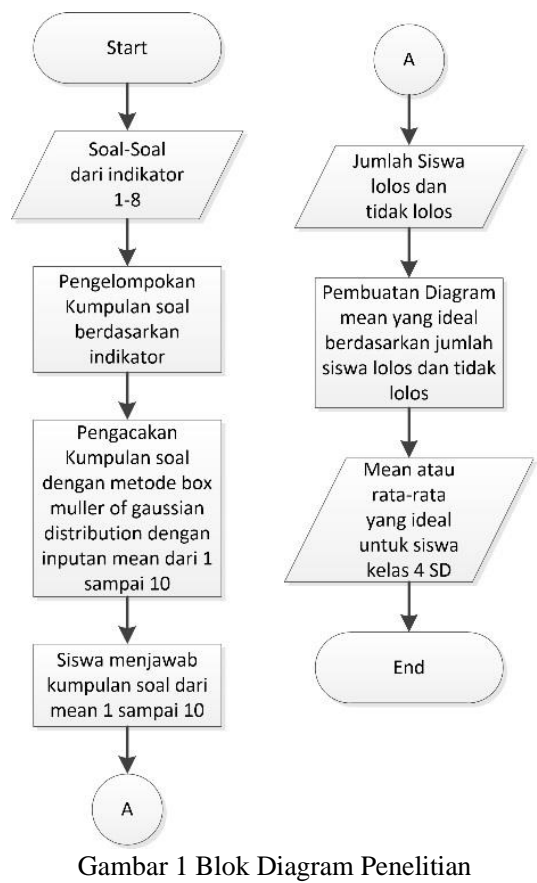

Penentuan tingkat kesulitan game pada penelitian ini langkah pertama yaitu pengumpulan soal-soal berdasarkan 8 indikator. Berikut ini merupakan 8 indikator soal-soal yang akan muncul.

1. Menjelaskan pengaruh faktor penyebab perubahan lingkungan terhadap daratan.

2. Menjelaskan tipe-tipe gunung api.

3. Mendemonstrasikan proses erupsi gunung api.

4. Mengidentifikasi berbagai dampak yang ditimbulkan dari erupsi gunung api.

5. Menjelaskan bahaya yang ditimbulkan dari adanya erupsi gunung api.

6. Mengidentifikasi langkah-langkah mitigasi bencana.

7. Mengidentifikasi langkah-langkah mitigasi bencana sebelum terjadi erupsi gunung api.

8. Mengidentifikasi langkah-langkah mitigasi bencana pada saat terjadi erupsi gunung api.

Langkah kedua pengelompokan soal-soal berdasarkan indikator menjadi kumpulan soal. Indikator 1 sampai 4 merupakan indikator yang akan muncul pada level 1 . Indikator 5 sampai 8 merupakan indikator yang akan muncul pada level 2. Sedangkan pada level 3 merupakan gabungan dari indikator 1 sampai 8. Setelah pengelompokan selesai, kumpulan soal ini akan diacak oleh Box Muller of Gaussian Distribution untuk mencari mean / rata-rata yang ideal untuk ditampilkan kedalam game. Pada proses pengacakan ini mean dari algoritma box muller akan diganti dari 1 sampai 10. Setiap nilai mean yang diubah akan menghasilkan kumpulan soal yang berbeda. Satu siswa dengan siswa lain tingkat kesulitannya akan berbeda, tergantung dengan tingkat kemampuan siswa dalam menyelesaikan pertanyaan-pertanyaan yang akan muncul pada game. Setelah diketahui jumlah lolos menuju level selanjutnya atau tidak maka dapat ditentukan mean yang ideal dari siswa tersebut dengan cara membuat diagram dari data jumlah lolos dan tidak lolos. Mean tersebut merupakan tingkat kesulitan pada 
game untuk siswa kelas 4 SD yang akan dimasukkan kedalam game.

\section{B. Box Muller of Gaussian Distribution}

Secara umum Box Muller of Gaussian Distribution merupakan metode untuk menentukan nilai mean dari Gaussian Distribution dengan menggunakan metode box muller. Box Muller of Gaussian Distribution digunakan pada saat awal permainan untuk penyesuaian tingkat kesulitan pada level selanjutnya. Sebagai contoh; pemain yang hanya menjawab 4 dari 10 dengan benar akan mendapatkan skor total 40 . skor total 40 tercakup dalam interval $40<$ skor total $\leq 50$ dan diklasifikasikan dapat melanjutkan ke gerbang berikutnya dengan tingkat kesulitan yang lebih tinggi.

\section{Pseudocode algoritma Box-Muller:}

1. Generate uniform random number $\mathrm{u}, \mathrm{v}$ in range $[-1$, $1]$.

2. Calculate $\mathrm{s}=\mathrm{u} 2+\mathrm{v} 2$

3. Looping step 2 until $\mathrm{s}<1$

4. Find normal random numbers $\mathrm{z} 0=\mathrm{u}$. $\sqrt{ }((-2 \operatorname{lns}) / \mathrm{s})$ and $\mathrm{z} 1=\mathrm{v} \cdot \sqrt{ }(-(-2 \ln \mathrm{s}) / \mathrm{s})$

Dimana z0 dan z1 adalah variabel random independen yang terdistribusi normal standar. Dari pseudocode z0 dan z1 akan dimasukkan dalam game.

\section{SKENARIO TINGKAT KESULITAN}

Dalam melakukan perhitungan tingkat kesulitan yang sesuai dengan pemain (siswa SD kelas 4) maka diperlukan 10 siswa sebagai acuan untuk menentukan mean / rata-rata yang ideal.

\section{A. Skenario tingkat kesulitan Box Muller Of Gaussian Distribution}

Pada penelitian ini menggunakan 5 soal tentang materi IPA kelas 4, pada 5 soal tersebut terdapat 3 tingkat kesulitan yaitu easy, normal, dan hard. Tiap tingkat kesulitan soal tersebut memperoleh skor yang berbedabeda, easy mendapatakan skor 15, normal mendapatkan skor 20, dan hard mendapatkan skor 30. Pemain dapat melanjutkan ke level selanjutnya jika pemain mendapatkan total skor di atas atau sama dengan 75 . Namun jika pemain mendapatkan total skor kurang dari 75 maka pemain akan mengulang stage ini dengan menjawab 5 pertanyaan lain yang akan diacak dengan menggunakan metode Box Muller.

Berikut adalah detail dari desain kesulitan yang akan digunakan.

Q5 : if $71<$ total skor $\leq 100$

Q4 : if $61<$ total skor $\leq 70$

Q3 : if $31<$ total skor $\leq 50$

Q2 : if $16<$ total skor $\leq 30$

Q1 : if total skor $\leq 15$

Di perpustakaan akan terdapat soal-soal tentang materi IPA kelas 4 dengan indikator 1 sampai 4 . Indikator pertama menjelaskan pengaruh faktor penyebab perubahan lingkungan terhadap daratan. Indikator kedua menjelaskan tipe-tipe gunung api.
Indikator ketiga mendemonstrasikan proses erupsi gunung api. Indikator keempat mengidentifikasi berbagai dampak yang ditimbulkan dari erupsi gunung api.

Di kelas akan terdapat soal-soal tentang materi IPA kelas 4 dengan indikator 5 sampai 8. Indikator kelima menjelaskan bahaya yang ditimbulkan dari adanya erupsi gunung api. Indikator keenam mengidentifikasi langkah-langkah mitigasi bencana. Indikator ketujuh mengidentifikasi langkah-langkah mitigasi bencana sebelum terjadi erupsi gunung api. Indikator kedelapan mengidentifikasi langkah-langkah mitigasi bencana pada saat terjadi erupsi gunung api.

Di ruang guru akan terdapat soal-soal tentang materi IPA kelas 4 dengan indikator 1 sampai 8 . Pengelompokan soal di ruang guru sama dengan pengelompokan soal di perpustakaan dan ruang kelas. Pada ruang guru ini soal yang muncul adalah gabungan dari soal yang ada di perpustakaan dan di ruang kelas.

Berikut ini merupakan tampilan pertanyaan pada level 1 , bertempat di ruang kelas.

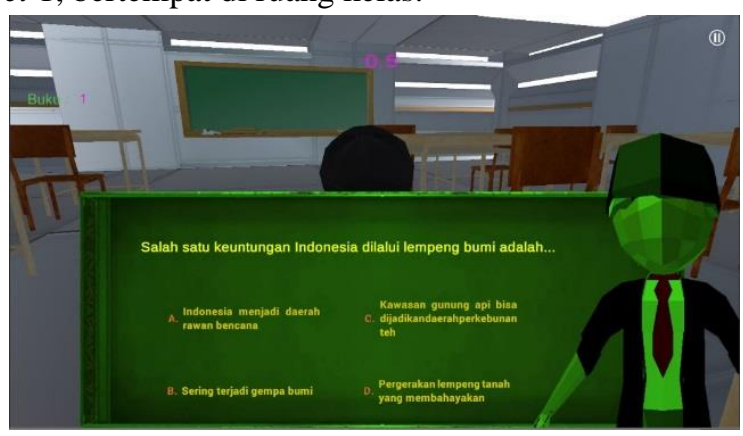

Gambar 1 Tampilan pertanyaan buku pertama di kelas

Gambar 1 merupakan tampilan jika pemain akan menjawab soal pada buku pertama di kelas. Dalam buku pertama ini soal yang muncul masing-masing terdapat 3 soal mudah, 1 soal normal, dan 1 soal sulit. Background pertanyaan pada buku pertama adalah hijau. Pada buku pertama terdapat pertanyaan dengan kesulitan mudah.

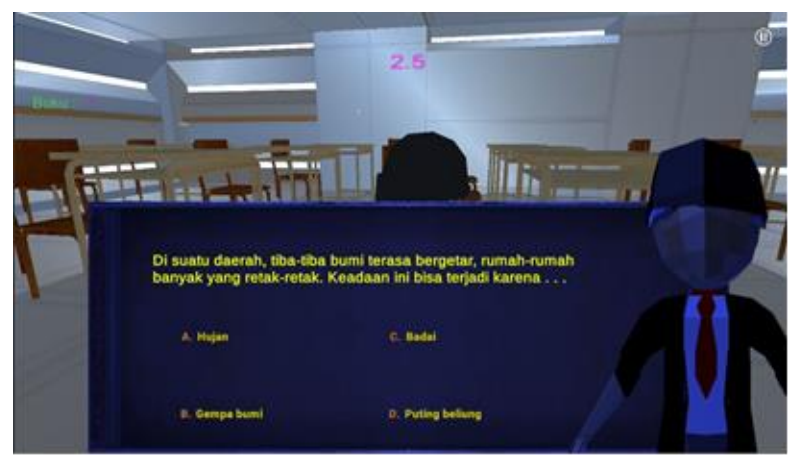

Gambar 2 Tampilan pertanyaan buku kedua di kelas

Gambar 2 merupakan tampilan jika pemain akan menjawab soal pada buku kedua di kelas. Dalam buku kedua ini soal yang muncul masing-masing terdapat 2 soal mudah, 2 soal normal, dan 1 soal sulit. Background pertanyaan pada buku kedua adalah biru. Pada buku kedua terdapat pertanyaan dengan kesulitan antara mudah dan normal. 


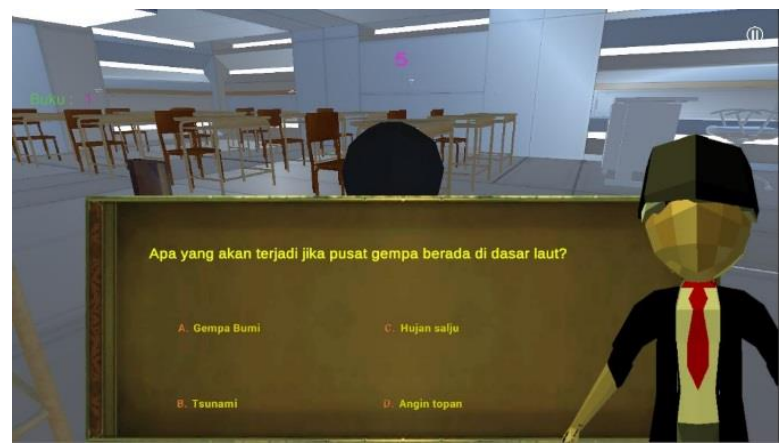

Gambar 3 Tampilan pertanyaan buku ketiga di kelas

Gambar 3 merupakan tampilan jika pemain akan menjawab soal pada buku ketiga di kelas. Dalam buku ketiga ini soal yang muncul masing-masing terdapat 1 soal mudah, 3 soal normal, dan 1 soal sulit. Background pertanyaan pada buku ketiga adalah kuning. Pada buku ketiga terdapat pertanyaan dengan kesulitan normal.

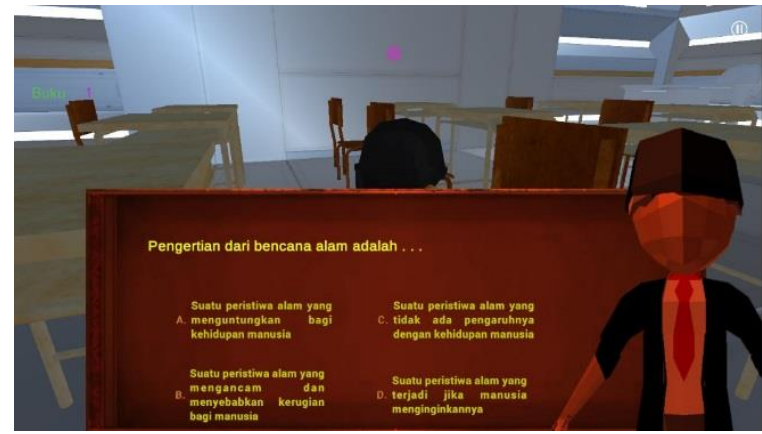

Gambar 4 Tampilan pertanyaan buku keempat di kelas

Gambar 4 merupakan tampilan jika pemain akan menjawab soal pada buku keempat di kelas. Dalam buku keempat ini soal yang muncul masing-masing terdapat 1 soal mudah, 2 soal normal, dan 2 soal sulit. Background pertanyaan pada buku ketiga adalah merah. Pada buku keempat terdapat pertanyaan dengan kesulitan sulit.

Berikut ini merupakan tampilan pertanyaan pada level 2, bertempat di ruang perpustakaan

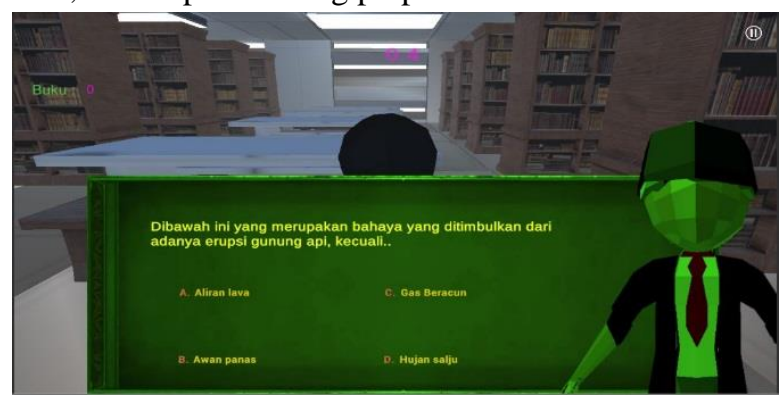

Gambar 5 Tampilan pertanyaan buku pertama di perpus

Gambar 5 merupakan tampilan jika pemain akan menjawab soal pada buku pertama di perpustakaan. Dalam buku pertama ini soal yang muncul masingmasing terdapat 3 soal mudah, 1 soal normal, dan 1 soal sulit. Background pertanyaan pada buku pertama adalah hijau. Pada buku pertama terdapat pertanyaan dengan kesulitan mudah.

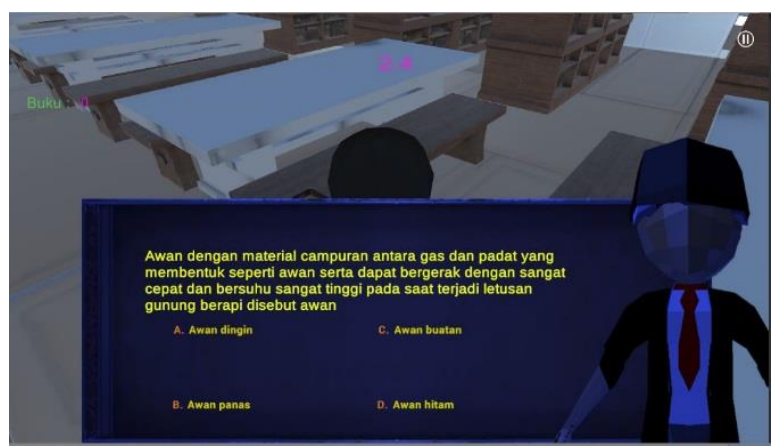

Gambar 6 Tampilan pertanyaan buku pertama di perpus

Gambar 6 merupakan tampilan jika pemain akan menjawab soal pada buku kedua di perpustakaan. Dalam buku kedua ini soal yang muncul masing-masing terdapat 2 soal mudah, 2 soal normal, dan 1 soal sulit. Background pertanyaan pada buku kedua adalah biru. Pada buku kedua terdapat pertanyaan dengan kesulitan antara mudah dan normal.

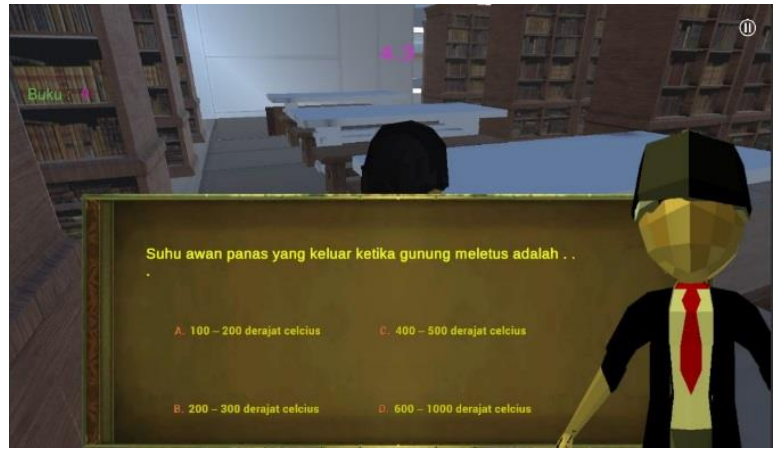

Gambar 7 Tampilan pertanyaan buku pertama di perpus

Gambar 7 merupakan tampilan jika pemain akan menjawab soal pada buku ketiga di perpustakaan. Dalam buku ketiga ini soal yang muncul masing-masing terdapat 1 soal mudah, 3 soal normal, dan 1 soal sulit. Background pertanyaan pada buku ketiga adalah kuning. Pada buku ketiga terdapat pertanyaan dengan kesulitan normal.

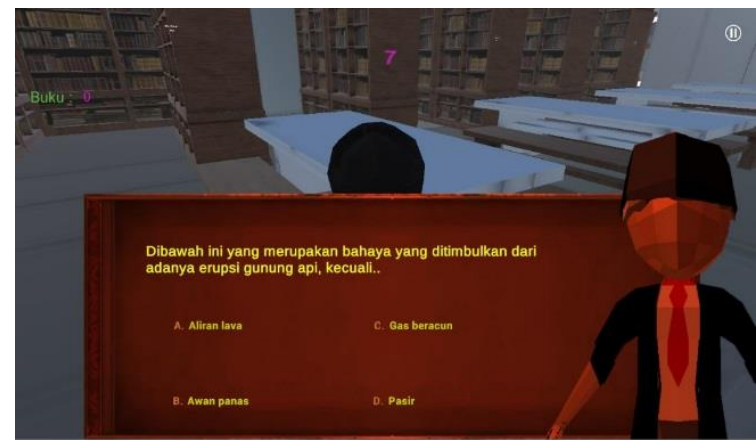

Gambar 8 Tampilan pertanyaan buku pertama di perpus

Gambar 8 merupakan tampilan jika pemain akan menjawab soal pada buku keempat di perpustakaan. Dalam buku keempat ini soal yang muncul masingmasing terdapat 1 soal mudah, 2 soal normal, dan 2 soal sulit. Background pertanyaan pada buku ketiga adalah merah. Pada buku keempat terdapat pertanyaan dengan kesulitan sulit.

Pada level ketiga terdapat di ruang guru. Berikut tampilan pertanyaannya. 


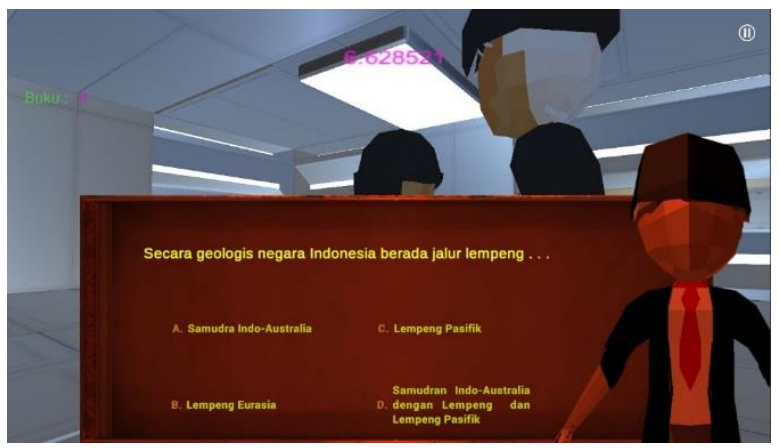

Gambar 9 Tampilan pertanyaan buku pertama di perpus

Gambar 9 merupakan tampilan jika pemain akan menjawab soal di ruang guru. Di ruang guru ini pemain akan menjawab satu kumpulan soal saja. Jika tingkat kesulitan soal sulit maka background soal berwarna merah, jika tingkat kesulitan soal normal maka background soal berwarna kuning, jika tingkat kesulitan soal antara normal dan mudah maka background soal berwarna biru, jika tingkat kesulitan soal mudah maka background soal berwarna hijau

\section{B. Prosedur Penelitian}

Pengujian akan dilakukan dengan murid kelas 4 SD. Pada awal permainan murid akan mengisi nama atau username dalam game. Setelah pemain menulis username, pemain diharuskan mencari 4 buku yang sudah diberi materi dan harus menjawab pertanyaan dengan benar. Jika pemain menemukan buku pertama maka pemain harus mempelajari materi yang akan muncul, setelah itu pemain harus menjawab pertanyaanpertanyaan yang muncul dengan benar dan harus mendapatkan skor di atas 75 untuk dapat mencari buku yang lain. Tetapi jika skor pemain pada buku pertama dibawah 75 maka harus mengulangi pertanyaan atau mencari buku yang lain dengan cara menekan tombol menyerah.

Terdapat 3 level pada game ini. Level 1 dan 2 jumlah pertanyaan yang disediakan adalah 40 soal. Terdapat 14 soal mudah, 16 soal normal dan 10 soal sulit. Sedangkan level 3 jumlah soalnya merupakan gabungan dari level 1 dan 2.

10 murid kelas $4 \mathrm{SD}$ akan mencoba menjawab pertanyaan yang sudah diacak dengan Box muller of Gaussian Distribution. Pengujian akan dilakukan dengan 10 kali percobaan. Tiap percobaan pada proses pengacakan dengan Box Muller of Gaussain Distribution akan dimasukkan mean atau rata-rata yang berbeda, yaitu mean 1-10. Setelah itu akan dicatat jumlah skor yang di atas 75 dan jumlah skor dibawah 75. Dari jumlah skor tersebut dapat menghasilkan mean/rata-rata idealnya untuk kesulitan siswa kelas 4 SD.

Selanjutnya mean atau rata-rata yang ideal tersebut akan dimasukkan kedalam game agar tingkat kesulitan dalam game sesuai dengan tingkat kemampuan murid kelas 4 SD. Tiap pemain memiliki tingkat kemampuan yang berbeda-beda, dengan adanya metode Box Muller of Gaussian Distribution ini tingkat kesulitan dapat berganti dari tingkat yang paling sulit, atau berganti ketingkat yang paling mudah.

\section{Uji Validasi}

Validasi behavior dilakukan untuk melihat tingkat completeness pemain dalam menyelesaikan misi yang ada. Pada salah satu jurnal menjelaskan bahwa validasi behavior ini digunakan untuk melihat tingkat completeness pemain dalam menyelesaikan misi dengan cara membandingkan skor yang didapatkan agen dan skor yang tersedia [7]. Pada validasi ini terdapat kolom completeness jika bernilai yang maka dapat dikatakan bahawa metode yang digunakan berhasil untuk mengatur tingkat kesulitan secara dinamik.

\section{HASIL UJi COBA DAN ANALISA}

Pada pengujian ini digunakan untuk melihat sistem dalam menjalankan algoritma yang telah dibuat. Dari 10 kali percobaan yang dilakukan oleh siswa kelas 4 SD, diperoleh data seperti tabel 1 .

Tabel 1 Jumlah lolos dan tidak lolos

\begin{tabular}{ccc}
\hline \hline & Lolos & Tidak Lolos \\
\hline$\mu=1$ & 2 & 8 \\
$\mu=2$ & 3 & 7 \\
$\mu=3$ & 2 & 8 \\
$\mu=4$ & 3 & 7 \\
$\mu=5$ & 4 & 6 \\
$\mu=6$ & 6 & 4 \\
$\mu=7$ & 9 & 1 \\
$\mu=8$ & 10 & 0 \\
$\mu=9$ & 10 & 0 \\
$\mu=10$ & 10 & 0 \\
\hline \hline
\end{tabular}

Pada tabel 1 merupakan hasil dari jumlah siswa yang lolos( skor di atas 75) dan tidak lolos( skor dibawah 75). Dari tabel 4.1 akan dibuat diagram jumlah skor berhasil dan jumlah skor gagal.

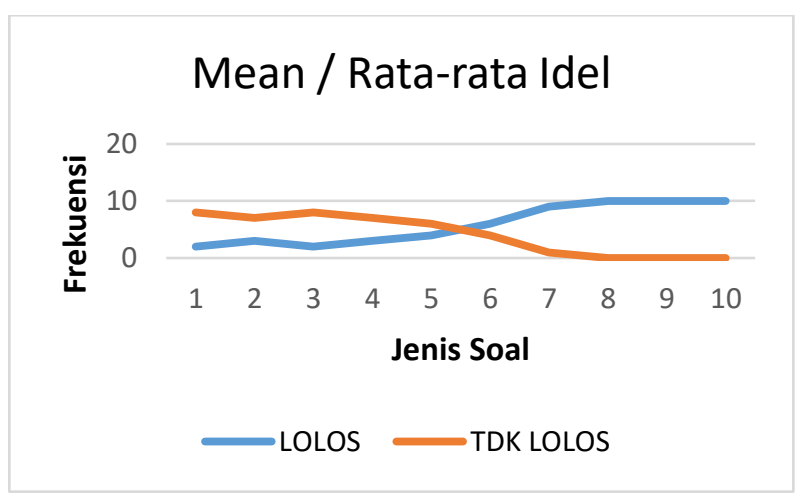

Gambar 10 Mean/rata-rata ideal siswa kelas 4 SD

Pada Gambar 10 merupakan diagram untuk mean atau rata-rata yang ideal untuk murid kelas 4 SD. Dari Gambar 1 dapat dilihat bahwa mean yang ideal adalah $\mu$ $=$ 5,5. Pada Gambar $1 \mu$ pada sumbu horizontal merupakan "jenis soal" yang mempresentasikan 10 kombinasi 5 jenis soal (mudah, normal, dan sulit). Sedangkan angka $0-12$ pada sumbu vertikal menyatakan (frekuensi) lolos dan tidak lolos.

Setelah mean/rata-rata yang ideal ditentukan, ratarata tersebut akan dimasukkan kedalam game 
Pembelajaran Mitigasi Bencana Alam Gunung Api. Box Mulller of Gaussian Distribution akan melakukan pengacakan soal yang muncul sesuai dengan rata-rata ideal yang sebelumnya sudah dimasukkan.

Validasi hasil pengujian akan dilakukan uji coba oleh 5 siswa kelas 4 SD. Hasilnya ditampilkan pada tabel 4.3 sampai tabel 4.7. Pada kolom level terdapat jumlah level yang ada didalam game, pada game ini terdapat 3 level. Pada kolom tempat merupakan latar terjadi permainan pada tiap level. Pada kolom jumlah buku terdapat jumlah buku yang ada pada tiap level. Level pertama latar tempatnya di ruang kelas. Level kedua latar tempatnya di ruang perpustakaan. Level ketiga latar tempatnya di ruang guru. Pada kolom Coba Ulang merupakan jumlah percobaan untuk mengacak kumpulan soal supaya pemain dapat memenuhi syarat untuk menuju misi selanjutnya. Pada kolom skor yang diinginkan merupakan skor minimal supaya dapat dikatakan pemain berhasil untuk menuju level selanjuntya pada game ini mminial skornya 75. Pada kolom persentase keberhasilan merupakan persentase pemain untuk menyelesaikan misi untuk menuju misi selanjutnya. Persentase keberhasilan dihitung dengan rumus. Kolom compeleteness merupakan apakah misi pada masing-masing buku terpenuhi atau tidak. Dalam game ini dapat dikatakan misi terpenuhi jika pemain mendapatkan skor di atas 75 pada saat menjawab soal yang muncul.

\begin{tabular}{|c|c|c|c|c|c|c|c|c|c|}
\hline \multirow{2}{*}{$\begin{array}{l}L \\
e \\
v \\
e l \\
\end{array}$} & \multirow{2}{*}{$\begin{array}{l}\mathrm{Te} \\
\mathrm{mp} \\
\text { at }\end{array}$} & \multirow{2}{*}{$\begin{array}{l}\mathrm{Jm} \\
1 \\
\mathrm{Bu} \\
\mathrm{ku} \\
\end{array}$} & \multicolumn{4}{|c|}{ Coba Ulang } & \multirow{2}{*}{$\begin{array}{l}\text { skor } \\
\text { yang } \\
\text { diingi } \\
\text { nkan }\end{array}$} & \multirow{2}{*}{$\begin{array}{l}\text { Perse } \\
\text { ntase } \\
\text { berha } \\
\text { sil } \\
\end{array}$} & \multirow{2}{*}{$\begin{array}{l}\text { com } \\
\text { plet } \\
\text { ene } \\
\text { ss } \\
\end{array}$} \\
\hline & & & 1 & 2 & 3 & 45 & & & \\
\hline \multirow{4}{*}{$\begin{array}{l}l e \\
v \\
e l \\
1\end{array}$} & \multirow{4}{*}{$\begin{array}{l}\text { kela } \\
\text { s }\end{array}$} & 1 & - & $\begin{array}{l}\text { be } \\
\text { rh } \\
\text { as } \\
\text { il }\end{array}$ & & & $\begin{array}{l}\text { 75/ber } \\
\text { hasil }\end{array}$ & 50 & уа \\
\hline & & 2 & - & $\begin{array}{l}\text { be } \\
\text { rh } \\
\text { as } \\
\text { il }\end{array}$ & & & $\begin{array}{l}\text { 75/ber } \\
\text { hasil }\end{array}$ & 50 & ya \\
\hline & & 3 & $\begin{array}{l}\text { be } \\
\text { rh } \\
\text { as } \\
\text { il }\end{array}$ & & & & $\begin{array}{l}\text { 75/ber } \\
\text { hasil }\end{array}$ & 100 & ya \\
\hline & & 4 & - & $\begin{array}{l}\text { be } \\
\text { rh } \\
\text { as } \\
\text { il }\end{array}$ & & & $\begin{array}{l}\text { 75/ber } \\
\text { hasil }\end{array}$ & 50 & ya \\
\hline
\end{tabular}

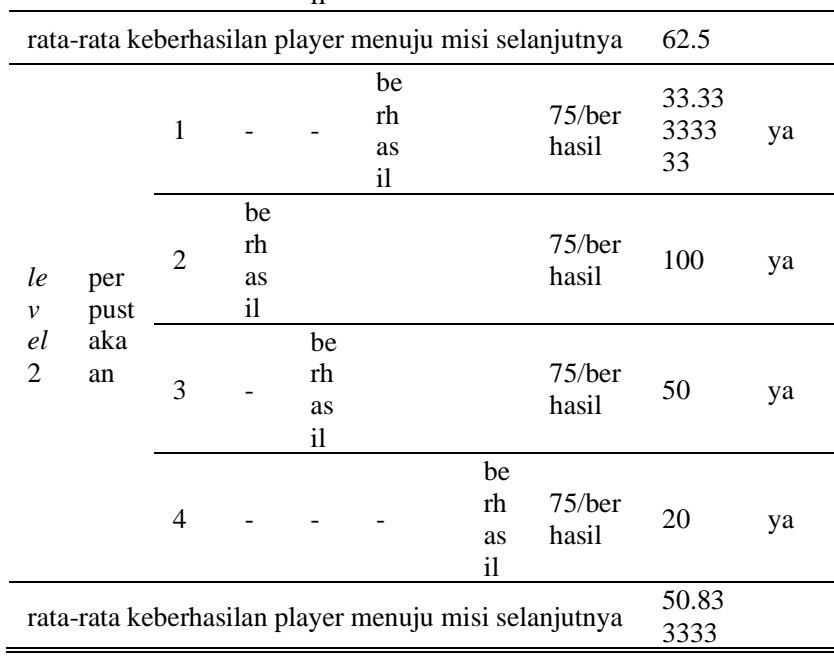

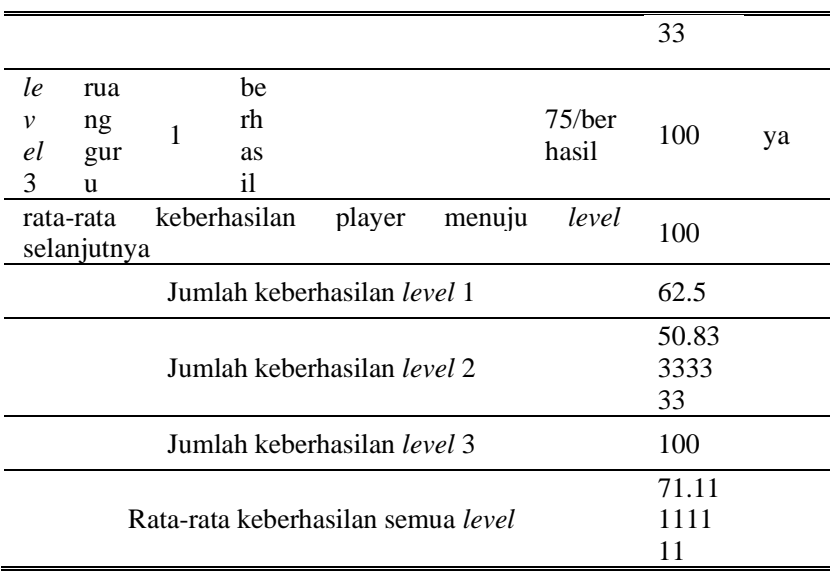

Pada tabel 2 merupakan hasil uji coba siswa pertama. Pada baris Jumlah keberhasilan level $1=62.5$, Jumlah keberhasilan level $2=50.8333$, dan Jumlah keberhasilan level $3=100$. Maka persentase rata-rata keberhasilan pemain pertama dalam menyelesaikan game ini adalah $71.1111 \%$, terletak pada baris terakhir tabel 2 .

Dari tabel 2 di atas dapat dilihat bahwa kolom completeness memiliki nilai "ya" semua. Maka hal ini mengindikasikan bahwa penerapan metode Box Muller of Gaussian Distribution berhasil dilakukan. Dan angka 71.11111111 merupakan persentase tingkat keberhasilan pemain pertama dalam menyelesaikan game Pembelajaran Mitigasi Bencana Gunung Api.

\section{Tabel 3 Uji Coba Siswa Kedua}

\begin{tabular}{|c|c|c|c|c|c|c|c|c|c|}
\hline \multirow{2}{*}{$\begin{array}{l}L \\
e v \\
e l\end{array}$} & \multirow{2}{*}{$\begin{array}{l}\text { Te } \\
\text { mpa } \\
t\end{array}$} & \multirow{2}{*}{$\begin{array}{l}\mathrm{Jm} \\
1 \\
\mathrm{Bu} \\
\mathrm{ku} \\
\end{array}$} & \multicolumn{4}{|c|}{ Coba Ulang } & \multirow{2}{*}{$\begin{array}{l}\text { skor } \\
\text { yang } \\
\text { diingin } \\
\text { kan }\end{array}$} & \multirow{2}{*}{$\begin{array}{l}\text { Perse } \\
\text { ntase } \\
\text { berha } \\
\text { si } \\
\end{array}$} & \multirow{2}{*}{$\begin{array}{l}\text { com } \\
\text { plet } \\
\text { enes } \\
\text { s }\end{array}$} \\
\hline & & & 1 & 2 & 3 & 45 & & & \\
\hline \multirow{4}{*}{$\begin{array}{l}l e \\
v e \\
l \\
1\end{array}$} & \multirow{4}{*}{$\begin{array}{l}\text { kela } \\
\mathrm{s}\end{array}$} & 1 & - & $\begin{array}{l}\text { be } \\
\text { rh } \\
\text { as } \\
\text { il }\end{array}$ & & & $\begin{array}{l}75 / \text { ber } \\
\text { hasil }\end{array}$ & 50 & ya \\
\hline & & 2 & $\begin{array}{l}\text { be } \\
\text { rh } \\
\text { as } \\
\text { il } \\
\end{array}$ & & & & $\begin{array}{l}\text { 75/ber } \\
\text { hasil }\end{array}$ & 100 & ya \\
\hline & & 3 & $\begin{array}{l}\text { be } \\
\text { rh } \\
\text { as } \\
\text { il }\end{array}$ & & & & $\begin{array}{l}75 / \text { ber } \\
\text { hasil }\end{array}$ & 100 & ya \\
\hline & & 4 & $\begin{array}{l}\text { be } \\
\text { rh } \\
\text { as } \\
\text { il }\end{array}$ & & & & $\begin{array}{l}75 / \text { ber } \\
\text { hasil }\end{array}$ & 100 & ya \\
\hline & $\begin{array}{l}\text { rata } \\
\text { hutnya }\end{array}$ & keber & silan & & yer & menuju & misi & 87.5 & \\
\hline \multirow{4}{*}{$\begin{array}{l}\text { le } \\
v e \\
l \\
2\end{array}$} & \multirow{4}{*}{$\begin{array}{l}\text { perp } \\
\text { usta } \\
\text { kaa } \\
\text { n }\end{array}$} & 1 & - & $\begin{array}{l}\text { be } \\
\text { rh } \\
\text { as } \\
\text { il }\end{array}$ & & & $\begin{array}{l}\text { 75/ber } \\
\text { hasil }\end{array}$ & 50 & ya \\
\hline & & 2 & - & $\begin{array}{l}\text { be } \\
\text { rh } \\
\text { as } \\
\text { il }\end{array}$ & & & $\begin{array}{l}75 / \text { ber } \\
\text { hasil }\end{array}$ & 50 & ya \\
\hline & & 3 & $\begin{array}{l}\text { be } \\
\text { rh } \\
\text { as } \\
\text { il }\end{array}$ & & & & $\begin{array}{l}75 / \text { ber } \\
\text { hasil }\end{array}$ & 100 & ya \\
\hline & & 4 & - & - & $\begin{array}{l}\text { be } \\
\text { rh } \\
\text { as } \\
\text { il }\end{array}$ & & $\begin{array}{l}75 / \text { ber } \\
\text { hasil }\end{array}$ & $\begin{array}{l}33.33 \\
33333 \\
3\end{array}$ & ya \\
\hline \multicolumn{2}{|c|}{$\begin{array}{l}\text { rata-rata } \\
\text { selanjutnyc }\end{array}$} & \multicolumn{2}{|c|}{ keberhasilan } & \multicolumn{2}{|c|}{ player } & menuju & misi & $\begin{array}{l}58.33 \\
33333 \\
3\end{array}$ & \\
\hline
\end{tabular}




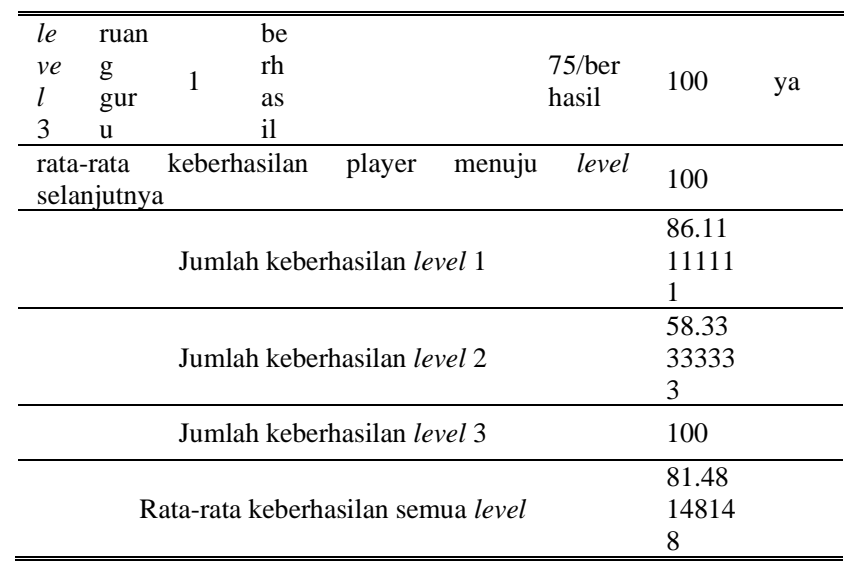

Pada tabel 3 merupakan hasil uji coba siswa kedua. Pada baris Jumlah keberhasilan level $1=86.1111$, Jumlah keberhasilan level $2=58.3333$, dan Jumlah keberhasilan level $3=100$. Maka persentase rata-rata keberhasilan pemain kedua dalam menyelesaikan game ini adalah $81.4814 \%$, terletak pada baris terakhir tabel 3 .

Dari tabel 3 di atas dapat dilihat bahwa kolom completeness memiliki nilai "ya" semua. Maka hal ini mengindikasikan bahwa penerapan metode Box Muller of Gaussian Distribution berhasil dilakukan. Dan angka 81.4814 merupakan persentase tingkat keberhasilan pemain kedua dalam menyelesaikan game Pembelajaran Mitigasi Bencana Gunung Api.

Tabel 4 Uji Coba Siswa Ketiga

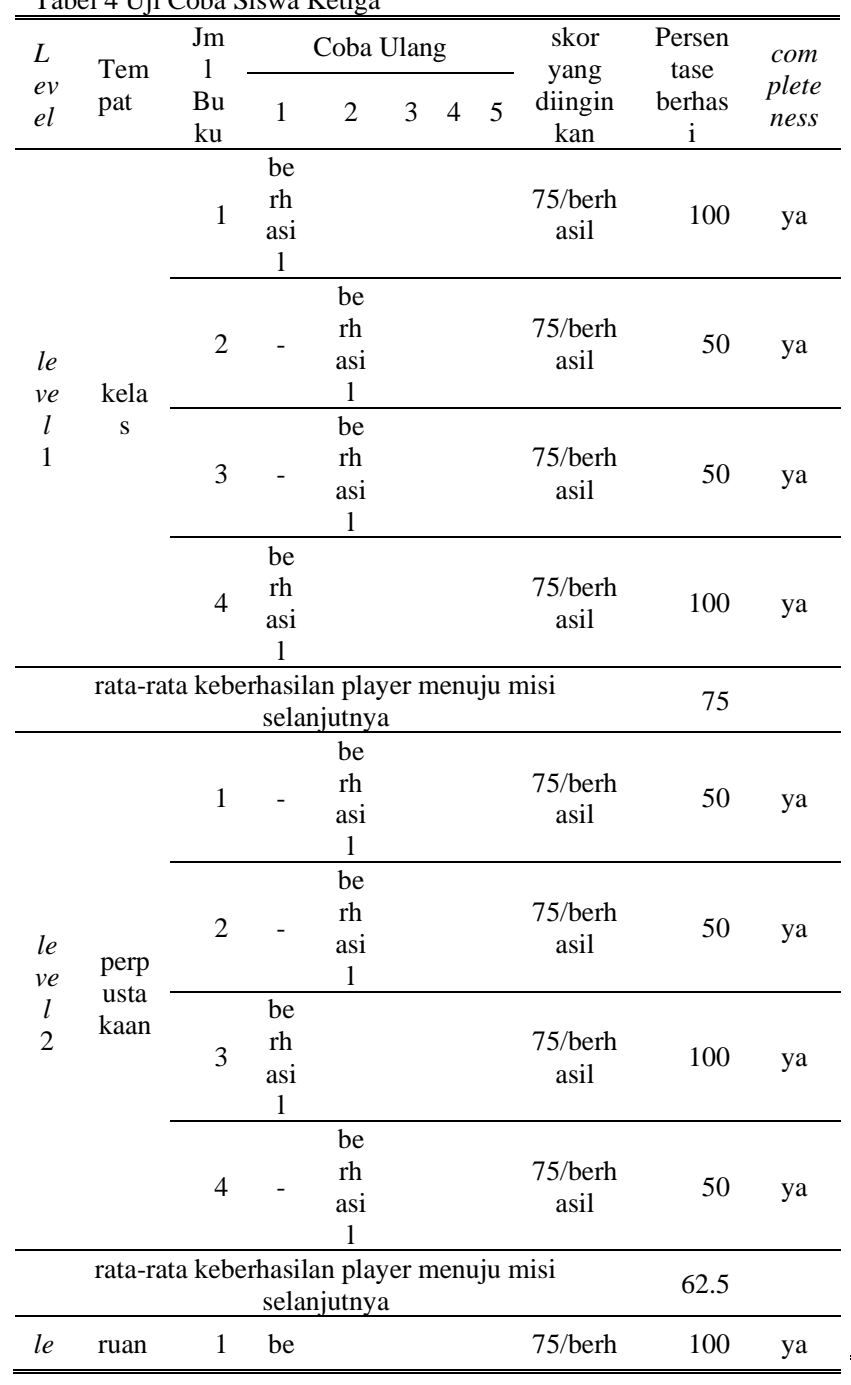

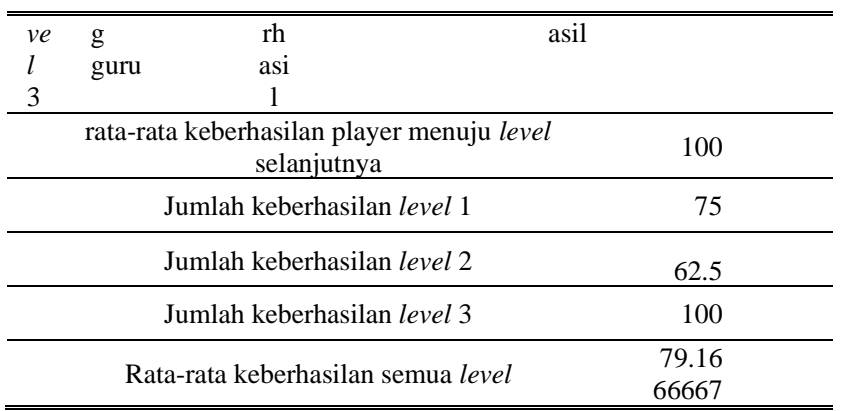

Pada tabel 4 merupakan hasil uji coba siswa ketiga. Pada baris Jumlah keberhasilan level $1=75$, Jumlah keberhasilan level $2=62.5$, dan Jumlah keberhasilan level $3=100$. Maka persentase rata-rata keberhasilan pemain ketiga dalam menyelesaikan game ini adalah $79.1667 \%$, terletak pada baris terakhir tabel 4 .

Dari tabel 4 di atas dapat dilihat bahwa kolom completeness memiliki nilai "ya" semua. Maka hal ini mengindikasikan bahwa penerapan metode Box Muller of Gaussian Distribution berhasil dilakukan. Dan angka 79.1667 merupakan persentase tingkat keberhasilan pemain ketiga dalam menyelesaikan game Pembelajaran Mitigasi Bencana Gunung Api.

Tabel 5 Uji Coba Siswa Keempat

\begin{tabular}{|c|c|c|c|c|c|c|c|c|c|}
\hline \multirow{2}{*}{$\begin{array}{l}L \\
e v \\
e l\end{array}$} & \multirow{2}{*}{$\begin{array}{c}\mathrm{Te} \\
\mathrm{mpa} \\
\mathrm{t}\end{array}$} & \multirow{2}{*}{$\begin{array}{c}\mathrm{Jm} \\
1 \\
\mathrm{Bu} \\
\mathrm{ku} \\
\end{array}$} & \multicolumn{4}{|c|}{ Coba Ulang } & \multirow{2}{*}{$\begin{array}{c}\text { skor } \\
\text { yang } \\
\text { diingin } \\
\text { kan } \\
\end{array}$} & \multirow{2}{*}{$\begin{array}{c}\text { Perse } \\
\text { ntase } \\
\text { berha } \\
\text { si } \\
\end{array}$} & \multirow{2}{*}{$\begin{array}{c}\text { com } \\
\text { plet } \\
\text { enes } \\
s \\
\end{array}$} \\
\hline & & & 1 & 2 & 3 & 45 & & & \\
\hline \multirow{5}{*}{$\begin{array}{l}l e \\
v e \\
l \\
1\end{array}$} & \multirow{4}{*}{$\begin{array}{c}\text { kela } \\
\text { s }\end{array}$} & 1 & $\begin{array}{l}\text { be } \\
\text { rh } \\
\text { as } \\
\text { il }\end{array}$ & & & & $\begin{array}{l}75 / \text { ber } \\
\text { hasil }\end{array}$ & 100 & ya \\
\hline & & 2 & $\begin{array}{l}\text { be } \\
\text { rh } \\
\text { as } \\
\text { il }\end{array}$ & & & & $\begin{array}{l}75 / \text { ber } \\
\text { hasil }\end{array}$ & 100 & ya \\
\hline & & 3 & $\begin{array}{l}\text { be } \\
\text { rh } \\
\text { as } \\
\text { il }\end{array}$ & & & & $\begin{array}{l}75 / \text { ber } \\
\text { hasil }\end{array}$ & 100 & ya \\
\hline & & 4 & $\begin{array}{l}\text { be } \\
\text { rh } \\
\text { as } \\
\text { il }\end{array}$ & & & & $\begin{array}{c}75 / \text { ber } \\
\text { hasil }\end{array}$ & 100 & уа \\
\hline & rata-r & ta keb & $\begin{array}{l}\text { has } \\
\text { se }\end{array}$ & $\mathrm{n}$ & tr & enuju $\mathrm{m}$ & & 100 & \\
\hline \multirow{5}{*}{$\begin{array}{l}l e \\
v e \\
l \\
2\end{array}$} & \multirow{4}{*}{$\begin{array}{c}\text { perp } \\
\text { usta } \\
\text { kaa } \\
\text { n }\end{array}$} & 1 & $\begin{array}{l}\text { be } \\
\text { rh } \\
\text { as } \\
\text { il }\end{array}$ & & & & $\begin{array}{l}75 / \text { ber } \\
\text { hasil }\end{array}$ & 100 & ya \\
\hline & & 2 & - & $\begin{array}{l}\text { be } \\
\text { rh } \\
\text { as } \\
\text { il }\end{array}$ & & & $\begin{array}{l}75 / \text { ber } \\
\text { hasil }\end{array}$ & 50 & ya \\
\hline & & 3 & $\begin{array}{l}\text { be } \\
\text { rh } \\
\text { as } \\
\text { il }\end{array}$ & & & & $\begin{array}{l}75 / \text { ber } \\
\text { hasil }\end{array}$ & 100 & ya \\
\hline & & 4 & - & - & $\begin{array}{l}\text { be } \\
\text { rh } \\
\text { as } \\
\text { il }\end{array}$ & & $\begin{array}{c}75 / \text { ber } \\
\text { hasil }\end{array}$ & $\begin{array}{r}33.33 \\
33333 \\
3\end{array}$ & ya \\
\hline & \multicolumn{7}{|c|}{$\begin{array}{l}\text { rata-rata keberhasilan player menuju misi } \\
\text { selanjutnya }\end{array}$} & $\begin{array}{r}70.83 \\
33333 \\
3 \\
\end{array}$ & \\
\hline $\begin{array}{l}\text { le } \\
\text { ve } \\
\text { l } \\
3 \\
\end{array}$ & $\begin{array}{l}\text { ruan } \\
\mathrm{g} \\
\text { gur } \\
\mathrm{u} \\
\end{array}$ & 1 & - & $\begin{array}{l}\text { be } \\
\text { rh } \\
\text { as } \\
\text { il }\end{array}$ & & & $\begin{array}{l}75 / \text { ber } \\
\text { hasil }\end{array}$ & 50 & ya \\
\hline
\end{tabular}




\begin{tabular}{cr}
\hline \hline $\begin{array}{c}\text { rata-rata keberhasilan player menuju level } \\
\text { selanjutnya }\end{array}$ & 50 \\
\hline Jumlah keberhasilan level 1 & 100 \\
\hline Jumlah keberhasilan level 2 & 70.83 \\
& 33333 \\
Jumlah keberhasilan level 3 & 50 \\
\hline Rata-rata keberhasilan semua level & 73.61 \\
& 1111 \\
\hline
\end{tabular}

Pada tabel 5merupakan hasil uji coba siswa keempat. Pada baris Jumlah keberhasilan level $1=100$, Jumlah keberhasilan level $2=70.8333$, dan Jumlah keberhasilan level $3=50$. Maka persentase rata-rata keberhasilan pemain keempat dalam menyelesaikan game ini adalah $73.6111 \%$, terletak pada baris terakhir tabel 5 .

Dari tabel 5 di atas dapat dilihat bahwa kolom completeness memiliki nilai "ya" semua. Maka hal ini mengindikasikan bahwa penerapan metode Box Muller of Gaussian Distribution berhasil dilakukan. Dan angka 73.6111 merupakan persentase tingkat keberhasilan pemain keempat dalam menyelesaikan game Pembelajaran Mitigasi Bencana Gunung Api.

Tabel 6 Uji Coba Siswa Kelima

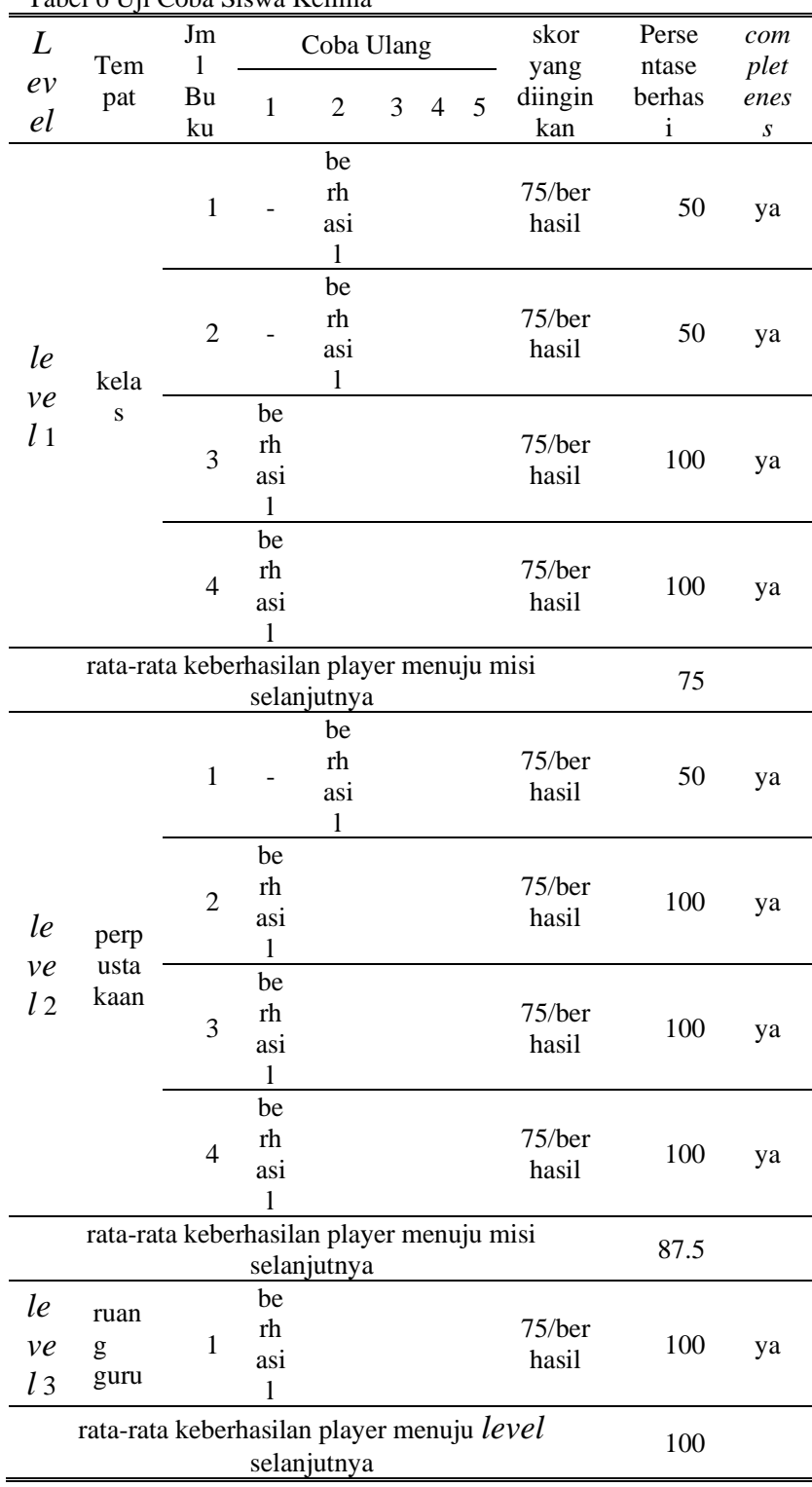

\begin{tabular}{cc}
\hline \hline Jumlah keberhasilan level 1 & 75 \\
\hline Jumlah keberhasilan level 2 & 87.5 \\
\hline Jumlah keberhasilan level 3 & 100 \\
\hline Rata-rata keberhasilan semua level & 87.5 \\
\hline \hline
\end{tabular}

Pada tabel 6 merupakan hasil uji coba siswa kelima. Pada baris Jumlah keberhasilan level $1=75$, Jumlah keberhasilan level $2=87.5$, dan Jumlah keberhasilan level $3=100$. Maka persentase rata-rata keberhasilan pemain kelima dalam menyelesaikan game ini adalah $87.5 \%$, terletak pada baris terakhir tabel 6 .

Dari tabel 6 di atas dapat dilihat bahwa kolom completeness memiliki nilai "ya" semua. Maka hal ini mengindikasikan bahwa penerapan metode Box Muller of Gaussian Distribution berhasil dilakukan. Dan angka 87.5 merupakan persentase tingkat keberhasilan pemain kelima dalam menyelesaikan game Pembelajaran Mitigasi Bencana Gunung Api.

\section{KESIMPULAN}

Berdasarkan skenario tingkat kesulitan pada game Pembelajaran Mitigasi Bencana Gunung Api yang telah dibuat serta pengujian yang sudah dilakukan, didapatkan kesimpulan dimana peneliti berhasil membuat skenario tingkat kesulitan game Pembelajaran Mitigasi Bencana Gunung Api menjadi skenario tingkat kesulitan secara dinamis atau otomatis dengan mengunakan metode Box Muller of Gaussian Distribution. Berdasarkan uji coba yang dilakukan oleh 10 siswa kelas $4 \mathrm{SD}$, menunjukkan bahwa tingkat kemampuan rata-rata siswa dalam bermain game Pembelajaran Mitigasi Bencana Gunung Api adalah sekitar mean $(\mu)=5,5$ dan standar deviasi $(\sigma)=1$.

\section{REFERENSI}

[1] Harsono, M. (2014). Pengaruh bermain game terhadap perkembangan remaja. Serpong: Surya University.

[2] Saurik, H. T. T., Yuniarno, E. M., \& Susiki, S. M. (2015). Kepuasan Pemain Terhadap Desain Rintangan Pada Skenario Game Petualang. Seminar Nasional Informatika 2015, 156-164.

[3] Roa, K. R., Boiroju, N. K., \& Reddy, M. K. (2011). Generation Of Standard Normal Random Variables. Indian J.Sci.Res, 2(4), 83-85.

[4] Sukajaya, I. N., Vitianingsih, A. V., Mardi, S. N. S., Purnama, K. E., Hariadi, M., \& Purnomo, M. H. (2012). Multiparameter dynamic difficulty game's scenario using Box-Muller of Gaussian distribution. 2012 7th International Conference on Computer Science \& Education (ICCSE), 1666-1671. https://doi.org/10.1109/ICCSE.2012.6295384

[5] Vitianingsih, A. V., \& Mardi, S. N. S. (2011). Distribusi Gaussian Untuk Dinamik Skenario Game Menggunakan Metode Box Muller. on The 12th Seminar on Intelligent Technology and Its Applications (SITIA). Dipresentasikan pada on The 12th Seminar on Intelligent Technology and Its Applications (SITIA).

[6] Ahmadi, I. A., Jonemaro, E. M. A., \& Akbar, M. A. (2018). Penerapan Algoritme Logika Fuzzy Untuk Dynamic Difficulty Scaling Pada Game Labirin. 2, 3609-3617.

[7] Ahsani, N. H., Jonemaro, E. M. A., \& Dewi, C. (2017). Penerapan Algoritma Monte Carlo Tree Search Pada Permainan Komputer Maze Treasure. 1, 1660-1667. 
